\title{
PERMAINAN SORTING COLOR DALAM MENINGKATKAN KEMAMPUAN KLASIFIKASI PRA-MATEMATIKA DI TAMAN KANAK-KANAK ISLAM BUDI MULIA PADANG
}

\author{
Winda Juniati ${ }^{1}$, Nur Hazizah, ${ }^{2}$ \\ Pendidikan Guru Pendidikan Anak Usia Dini Universitas Negeri Padang \\ E-mail: windajuniati405@gmail.com _nur_hazizah@fip.unp.ac.id
}

\begin{abstract}
Abstrak
Kemampuan klasifikasi matematika anak masih rendah karena kurangnya kemampuan guru dalam menciptakan susasana belajar anak. Sehingga penelitian ini bertujuan untuk meningkatkan kemampuan klasifikasi pra-matematika anak usia dini. Metode yang digunakan dalam penelitian ini adalah penelitian studi literatur. Yang dilatarbelakangi dengan pemahaman akan pentingnya kemampuan logika matematika yang berkaitan dengan perkembangan anak. Instrumen pengambilan data menggunakan pengumpulan literatur-literatur yang relevan dengan objek pembahasan. Hasil dari penelitian ini, menunjukkan bahwa besarnya pengaruh permainan sorting color dalam meningkatkan kemampuan klasifikasi pra matematika yang dapat membuat anak mampu mengelompokkan benda sesuai dengan warna, bentuk, ukuran serta beratnya.
\end{abstract}

\section{Kata Kunci: Klasifikasi,Pra-Matematika}

Abstract

The ability of children's mathematical classification is still low due to the lack of teacher's ability to create children's learning settings. So this study aims to improve the ability of pre-mathematical classification of early childhood. The method used in this research is literature study research. Which is motivated by an understanding of the importance of mathematical logic abilities related to child development. Data collection instruments use the collection of literature that is relevant to the object of discussion. The results of this study, indicate that the magnitude of the effect of color sorting games in improving the ability of pre-mathematical classification that can make children able to group objects according to color, shape, size and weight.

Keywords : classification, pre-mathematics

\section{PENDAHULUAN}

Anak merupakan amanah Allah yang kita rawat, dijaga, dan dibimbing agar menjadi manusia yang cerdas, bertaqwa, berkahlak mulia dan berilmu pengetahuan. Pendidikan adalah dasar dalam kemajuan dan perkembangan yang berkualitas, dengan adanya pendidikan manusia dapat meningkatkan semua kemampuan yang ada dalam dirinya,dapat mengoptimalkan manusia menjadi pribadi yang berilmu, sehingga terlahir sumber daya manusia yang berkompeten dimasa depan. Pendidikan merupakan proses yang tiada akhir, terdapat kesepakatan untuk melayani anak sejak usia kandungan sampai sepanjang hayat manusia. Pendidikan sepanjang hayat menjadi landasan munculnya kepedulian terhadap pendidikan sejak dalam kandungan dengan tahap-tahap usia dan perkembangannya yang disebut pendidikan anak usia dini. Anak usia dini adalah masa emas atau golden age yang berada pada rentang usia 0-8 tahun. Diusia tersebut anak mengalami perkembangan yang cepat sehingga memiliki potensi yang besar. (Wati, 2019).

Pendidikan anak usia dini adalah pendidikan yang sangat penting bagi anak dan perlu mendapat penanganan yang benar di usia dini . Usia 4-5 tahun merupakan periode sensitif atau masa peka pada anak, yaitu suatu periode dimana suatu fungsi tertentu perlu distimulus, diarahkan sehingga tidak terhambat perkembangannya. Kecerdasan logika

\section{Permainan Sorting Color (Juniarti; Hazizah) 143}


matematika merupakan suatu kemampuan yang dimiliki anak untuk mengklasifikasikan yang berkaitan dengan obyek khususnya ketika sebuah gambar seorang anak menikmati menghitung hal-hal yang dia hadapi dalam lingkungannya muncul dalam pikirannya (May Lwin et.al, 2005:47). Anak-anak yang memiliki rasa keingintahuan yang besar itu menunjukkan kemampuan logika matematikanya berkembang.

Menurut Mercer dalam Astari (2019:2) bahwa kemampuan dalam klasifikasi merupakan kemampuan anak sebelum meguasai konsep angka, anak terlebih dahulu mengenal persamaan dan perbedaan dari sejumlah benda, seperti warna, bentuk ataupun berdasarkan fungsinya. Selanjutnya, Charles dan Lind dalam Janice (2013:284) berpendapat bahwa kemampuan anak-anak dalam mengamati dimulai dari membandingkan dan mempertentangkan kesamaan dan perbedaan. Sedangkan Janice (2013:276) berpendapat bahwa pentingnya klasifikasi matematika bagi anak- anak adalah untuk memperluas pengetahuan yang ada pada anak. Dengan kita memberi nama objek bisa mendorong anak-anak agar dapat mengamati berbagai benda-benda dan membantu mendapatkan informasi baru.

Penelitian yang dilakukan oleh Naili Rohmah (2016) dengan judul penelitian keefektifan pembelajaran kooperatif melalui media dadu dalam pengembangan kemampuan matematika bagi anak usia dini yang hasilnya anak-anak mampu mengenal benda dengan mengelompokkan berbagai benda dilingkungannya berdasarkan warna,ukuran,pola,fungsi,sifat,suara,dan ciri-ciri lainnya. Pra-matematika merupakan kemampuan dalam menyelesaikan berbagai persoalan yang dihadapi anak-anak dalam kehidupan sehari-hari. Dimana pra matematika itu terdiri dari pola-pola, urutan, pengklasifikasian, ukuran, konsep, bilangan, korespondensi satu-satu, dan konsep bentuk geometri. Kegiatan ini bisa melatih anak untuk dapat memahami konsep bilangan dan operasi bilangan. Pola merupakan salah satu yang harus dipahami oleh anak usia dini dalam konsep pra-matematika. Pola (pattern) terdiri dari berbagai rangkaian warna, bagianbagian, benda-benda, ukuran, suara-suara dan gerakan-gerakan yang dapat diulang (Lasuka,2018). Dalam memahami konsep matematika anak usia dini anak belajar dimulai dari mencocokkan, mengklasifikasikan, atau menempatkan benda-benda sesuai bentuk atau kategori tertentu, membandingkan, dan persamaan.

\section{METODE PENELITIAN}

Jenis penelitian yang digunakan adalah penelitian studi literatur. Menurut Sugiyono (2013) penelitian studi literatur adalah penelitian yang mencari,mengumpulkan dan menganalisa referensi yang relevan tersebut dari berbagai sumber yang ada seperti buku-buku,majalah,arsip,jurnal,artikel serta dokumen-dokumen yang sesuai dengan permasalahan yang ada. Artinya dalam penelitian studi literatur yang akan dilakukan akan mencari sumber-sumber dari dokumen yang relevan untuk menjelaskan hubungan permainan sorting color dalam meningkatkan kemampuan klasifikasi pra-matematika di taman kanak-kanak islam budi mulia padang. Sumber data dalam penelitian ini, yaitu data primer. Data primer dalam penelitian ini adalah hasil penelitian atau tulisan-tulisan ilmiah atau teoritis yang relevan dengan hubungan permainan sorting color dalam meningkatkan kemampuan klasifikasi pra-matematika di taman kanak-kanak islam budi mulia padang. Hasil penelitian atau tulisan-tulisan ilmiah ini bisa ditemukan pada database online seperti Google Scholar, ERIC, Z-library, dan sejenisnya. 


\section{HASIL DAN PEMBAHASAN}

\section{Konsep Anak Usia Dini dan Pendidikan AUD}

Anak usia dini merupakan anak rentang usia 0-8 tahun yang mengalami suatu proses perkembangan dengan sehat dan fundamental bagi kehidupan selanjutnya. Proses pertumbuhan dan perkembangan sangat pesat dalam berbagai aspek dalam rentang kehidupan manusia sejak usia dini. Pada masa ini, kualitas hidup seseorang memiliki makna dan pengaruh yang luar biasa untuk kehidupan berikutnya. Anak usia dini memiliki karakteristik yang berbeda sesuai tahapan usianya seperti, anak bersifat egosentris, anak memiliki rasa ingin tahu yang tinggi, bersifat unik, kaya imajinasi, dan fantasi, serta anak memiliki daya kosentrasi yang singkat. Karakteristik anak usia dini adalah usia kelompok, usia menjelajah, usia bertanya, usia meniru, dan usia kreatif. Awal masa kanak-kanak baik di rumah atau di lingkungan prasekolah merupakan masa persiapan yang sangat penting bagi anak.

Pendidikan memberi kesempatan bagi anak untuk mengembangkan kepribadian dan potensi yang lebih optimal sejak usia dini. Suyadi \& Ulfah (2015: 17) menyatakan bahwa pendidikan anak usia dini adalah pendidikan yang diselenggarakan dengan tujuan untuk memfasilitasi atau mendukung pertumbuhan dan perkembangan anak secara menyeluruh atau menekankan agar seluruh aspek kepribadian anak dapat berkembang. Tujuan dari pendidikan anak usia dini adalah memberikan pengetahuan dan pemahaman orang tua dan guru terhadap perkembangan anak usia dini. Tujuan pendidikan anak usia dini secara umum adalah untuk dapat mengembangkan potensi anak sejak dini sebagai persiapan untuk hidup, dapat menyesuaikan diri dengan lingkungan serta meningkatkan keterampilannya.

\section{Matematika}

Menurut Brewer (2007:24-25) matematika adalah suatu pengetahuan tentang bilangan dan operasi bilangan, hubungan, gabungan, penyamarataan, dan pemisahan, dan bentuk ruang dan susunannya, ukuran, transformasi/perubahan. Pembelajaran matematika bagi anak harus menggunakan kedua potensi anak, baik intelektual maupun fisik. Mereka harus menjadi pelajar yang aktif, ditantang untuk menerapkan pengetahuan utama dan pengalaman baru mereka serta makin bertambahnya situasi-situasi yang lebih sulit.

Permainan matematika adalah kegiatan belajar tentang konsep matematika melalui aktifitas bermain dalam kehidupan sehari-hari dan bersifat alamiah. Matematika diperlukan untuk menumbuh kembangkan keterampilan berhitung, pengenalan balok, geometri, puzzle, pengukuran, volume yang sangat diperlukan dalam kehidupan sehari-hari. Menurut Utoyo (2017:27-28) matematika memiliki tujuan lebih dibandingkan dengan bahasa verbal. Karena matematika mampu mengembangkan bahasa numerik yang memungkinkan kegiatan secara kuantitatif seperti pengukuran. Tujuan pembelajaran matematika anak usia dini sebagai logico-mathematical learning atau berfikir logis dan matematis dengan cara yang menyenangkan dan tidak rumit. Tujuan pengenalan matematika secara umum untuk mengetahui dasar-dasar pembelajaran matematika, sehingga pada saatnya nanti akan lebih siap mengikuti pembelajaran matematika pada jenjang pendidikan selanjutnya yang lebih komplek.

Menurut Nisa (2016:116) Tujuan pengenalan matematika pada anak usia dini dibagi menjadi dua, yakni tujuan umum dan tujuan khusus. Tujuan umum pengenalan matematika adalah agar anak mengetahui dasar-dasar pembelajaran berhitung/matematika, sehingga pada saatnya nanti anak akan lebih siap mengikuti pembelajaran matematika pada jenjang pendidikan selanjutnya yang lebih kompleks. Sedangkan tujuan khususnya adalah 
dapat berpikir logis dan sistematis sejak dini melalui pengamatan terhadap benda-benda kongkrit, gambar-gambar atau angka-angka yang terdapat di sekitar anak; dapat menyesuaikan dan melibatkan diri dalam kehidupan masyarakat yang dalam kesehariannya memerlukan keterampilan berhitung; memiliki ketelitian, konsentrasi, abstraksi, dan daya apresiasi yang tinggi; memiliki pemahaman konsep ruang dan waktu serta dapat memperkirakan kemungkinan urutan sesuatu peristiwa terjadi di sekitarnya; serta memiliki kreativitas dan imajinasi dalam menciptakan sesuatu secara spontan.

\section{Pra-Matematika}

Menurut Lasuka (2018:18) Pra-matematika merupakan kemampuan dalam menyelesaikan berbagai persoalan yang dihadapi anak-anak dalam kehidupan sehari-hari, yang terdiri dari berbagai pola, urutan, pengklasifikasian, ukuran, konsep, bilangan, korespondensi satu-satu, dan konsep bentuk geometri. Kegiatan ini dapat melatih anak agar bisa memahami konsep dan operasi bilangan. Menurut Kennedy (2008:337) mencocokkan,mengklasifikasikan atau menempatkan benda-benda sesuai bentuk atau kategori, membandingkan, dan persamaan merupakan suatu konsep matematika anak usia dini yang harus dipelajari. Konsep matematika yaitu a) matching and discriminating, comparing, and contrasting, b) classifying, sorting and groupin, c) ordering, sequence and seriation. Menurut para ahli, matematika merupakan sebuah persoalan dalam kehidupan sehari-hari yang dapat diselesaikan oleh seorang anak terhadap kemampuan yang dikuasainya.. dimana terdiri dari berbagai pola, urutan, pengklasifikasian, ukuran, konsep bilangan, korespondensi satu-satu, konsep bentuk geometri, melakukan estimasi serta pengolahan data sederhana dengan memanipulasi dan menggunakan media-media konkret sebelum mengoperasikan simbol- simbol abstrak, serta melakukan interaksi melalui bermain.

Berdasarkan keputusan NCTM tahun 2000 mengemukakan bahwa komponen matematika sebagai berikut: (a) Konsep angka; (b) pola dan hubungannya; (c) Geometri dan orientasi spatial; (d) pengukuran; dan (e) pengumpulan (Jamaris, 2009). Konsep angka adalah kemampuan dasar di bidang matematika. Kemampuan ini berkembang secara bertahap dimulai dari kemampuan anak dalam mengeksplorasi dan memanipulasi objek dan selanjtnya diikuti dengan kemampuan anak dalam mengorganisasikannya dengan lingkungannya melalui logika matematika. Pola dan hubungan-hubungannya, merupakan susunan dari objek, bentuk bilangan. Pemahaman terhadap pola membantu anak dalam memahami hubungan-hubungan yang ada diantara objek, bentuk dan bilangan yang telah dikombinasikan kedalam polapola tertentu. Geometri dan orientasi spatial, berkaitan dengan kemampuan memahami bentuk dan strktur yang ada dalam lingkungan. Anak belajar untuk memahami bentuk tida dimensi pada waktu mereka diberikan balok-balok kecil yang dapat dijadikan alat bermain dan menciptakan berbagai bentuk objek seperti rumah, gedung, dan sebagainya.

\section{Klasifikasi}

Menurut Janice (2013:276) pentingnya klasifikasi matematika bagi anak usia dini adalah untuk memperluas pengetahuan mereka dan mendorong anak untuk dapat mengamati benda-benda berbeda dan membantu anak untuk dapat informasi baru. Selanjutnya karena anak-anak menduga benda-benda dalam satu kelompok serupa dalam cara tak jelas, mereka bisa mempelajari ciri-ciri ilmiah dengan baik sebelum usia taman kanakkanak.

Tahapan berpikir klasifikasi matematika menurut Micklo (dalam Janice J. Beaty,2013: 275) bahwa anak-anak mulai mengamati sifat-sifat sama dari objek, anak- 
anak bisa mulai memisahkan atau mengelompokkannya, kemampuan penting dalam perkembangan kognitif bagi otak mereka untuk memilah dan memproses limpahan data masuk yang diperoleh lewat kegiatan sensoris. Memilah objek dan material melatih anakanak dalam kemampuan ini dan melibatkan mengidentifikasi kesamaan objek serta memahami hubungannya. Tahapan kemampuan klasifikasi anak adalah: (1). Membandingkan adalah proses dimana anak membangun suatu hubungan antara dua benda berdasarkan atribut tertentu. Anak usia dini sering membuat perbedaan, terutama bila perbandingan itu melibatkan mereka secara pribadi (2). Menyusun adalah tingkat lebih tinggi dari perbandingan. Menyusun melibatkan perbandingan benda-benda yang lebih banyak, menempatkan benda-benda dalam satu urutan. Kegiatan menyusun dapat dilakukan didalam maupun luar kelas, misalnya menyusun buku yang diatur dari yang paling tebal, mengatur barisan dari anak yang paling tinggi atau pendek.

\section{PERMAINAN SORTING COLOR}

Sorting color asal kata dari bahasa inggris yang bisa kita artikan mengelompokkan atau membedakan warna. Mengelompokkan warna adalah bentuk kegiatan anak-anak dalam mengelompokkan warna sesuai dengan warna yang sama. Sebelum anak-anak memasuki mengenal angka dan berhitung, mengelompokkan warna merupakan satu kegiatan yang sangat penting bagi anak. Dengan belajar mengelompokkan benda berdasarkan warna, anak mengerti terhadap benda-benda yang memiliki kemiripan dan mengenal perbedaan, sehingga mereka bisa mengelompokkannya ke dalam satu group atau kelompok yang sama.

Menurut Sujiono dalam Lestari (2016:3) Kemampuan mengelompokkan benda sesuai warna adalah sarana pembelajaran anak usia dini dalam membedakan warna yang satu dengan yang lain. Kemampuan mengelompokkan benda sesuai warna merupakan fase perkembangan yang dimiliki oleh anak usia 4-5 tahun yaitu berfikir secara intuitif, anak sudah dapat mengklasifikasikan obyek sesuai dengan kelompoknya dan anak sudah menunjukkan minat dalam rasa dan perbedaan aktivitas sensori motor (warna, ukuran atau bentuk, suara, rasa, berat dan bau).

Berikut bahan-bahan yang digunakan untuk membuat permainan sorting color:

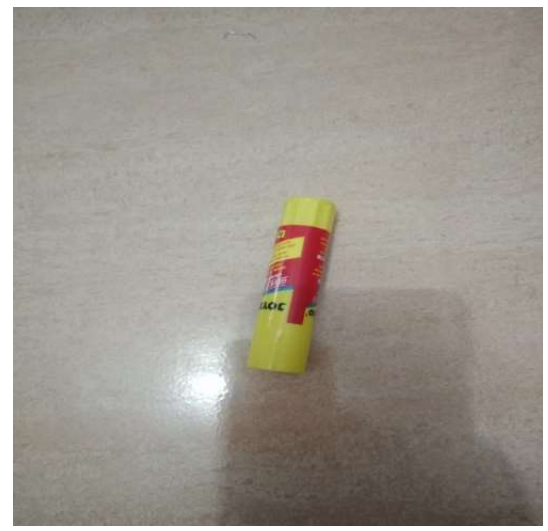

Gambar 1. Lem 
Jurnal Golden Age, Universitas Hamzanwadi

Vol. 04 No. 1, Juni 2020, Hal. 143-151

E-ISSN : 2549-7367

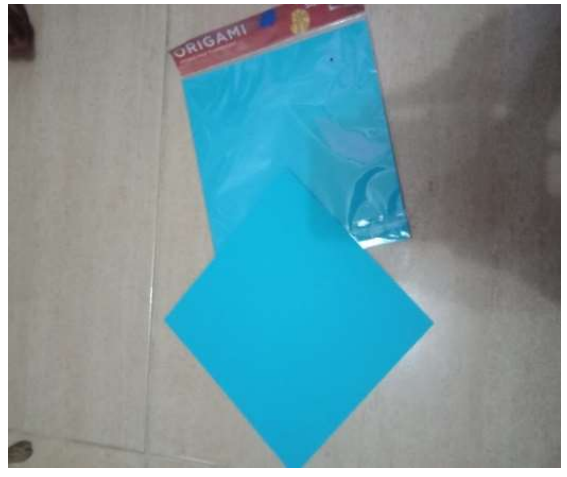

Gambar 2. Kertas Origami

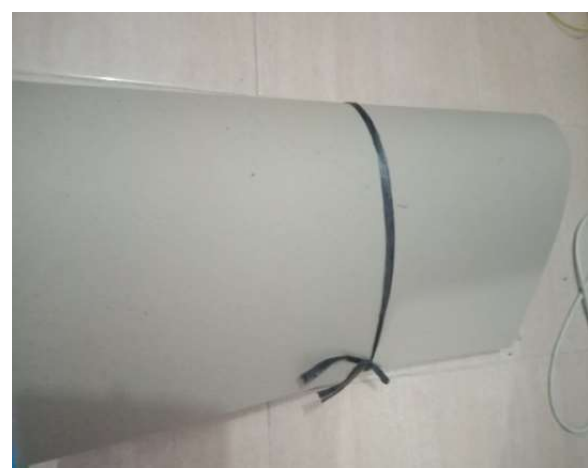

Gambar 3. Karton Jerami

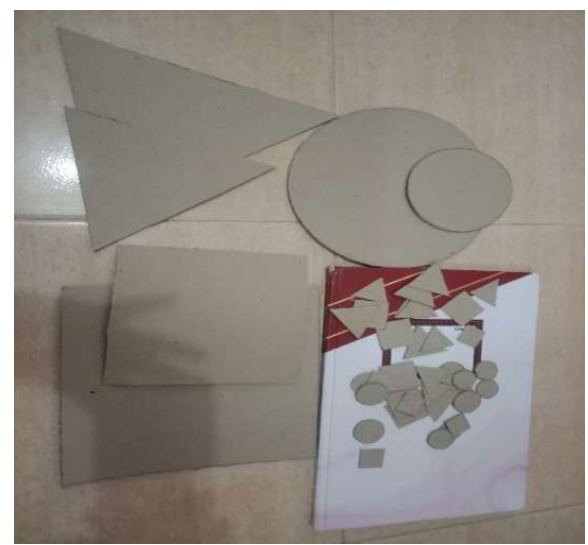

Gambar 4. Berbagai bentuk geometri (lingkaran,persegi,segitiga) 


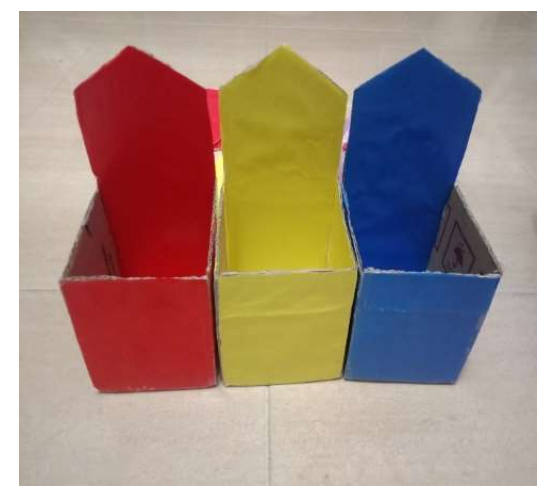

Gambar 5. Kotak tempat memasukkan berbagai geometri

\section{PENGARUH PERMAINAN SORTING COLOR DALAM MENINGKATKAN KEMAMPUAN KLASIFIKASI PRA-MATEMATIKA}

Permainan matematika memiliki pengaruh yang banyak bagi anak dalam kehidupan anak. Melalui permainan matematika ini, secara tidak langsung anak akan belajar mengenal banyak hal, diantaranya: Perkembangan social emosi Matematika dapat mengembangkan rasa percaya diri anak, cara yang dapat dilakukan antara lain: Mendorong keberanian dan memberi dukungan atas usaha anak, membuat anak percaya diri tanpa hilang rasa yakin, menerima pendapat yang diberikan anak.

\section{Perkembangan kreativitas}

Permainan matematika membuat anak dapat berfikir secara kreatif. Dengan cara membuat dan mengajukan berbagai pertanyaan dalam beberapa jawaban, serta melihatkan bahwa kreativitas anak dihargai. Perkembangan fisik Keterampilan fisik motorik anak juga dapat dikembangkan dengan adanya permainan matematika. Salah satu cara yang dapat mengembangkan kerampilan fisik motorik dari permainan matematika yaitu memberikan kebebasan kepada anak untuk bermain serta mendorong anak untuk bermain aktif. Perkembangan kognitif

Permainan matematika dapat mengembangkan kognitif yang berhubungan dengan keterampilan masalah. Cara yang dilakukan antara lain: Mengupayakan agar pemecahan masalah dibuat sesuai pengalaman, Tidak menyepelekan solusi yang kurang logis. Pengaruh permainan sorting color dalam meningkatkan kemampuan klasifikasi pra matematika adalah anak dapat mengetahui bagaimana cara mengelompokkan gambar sesuai warnanya,bentuk, ukuran dan juga berat dari gambar geometri. Dimana matematika merupakan hal yang penting dalam kehidupan kita karena dalam kehidupan sehari-hari kita tidak lepas dari penggunaan konsep-konsep dalam matematika seperti ketika kita belanja, menghitung benda, mengukur benda, dan lain-lain. Mengingat pentingnya matematika dalam kehidupan, maka konsep-konsep dalam matematika harus dikenalkan sejak dini. Konsep- konsep matematika yang harus dikenalkan pada anak usia dini diantaranya adalah membilang, geometri, pengukuran, seriasi, operasi bilangan, pola, pengklasifikasian, dan grafik. Dalam mengenalkan pada anak, akan lebih mudah dipahami jika anak diberi kesempatan untuk mengalami sendiri maupun menggunakan benda-benda konkret karena pada tahap ini anak belajar menggunakan simbol-simbol dan masih belum dapat berfikir secara sistematis. 


\section{SIMPULAN}

Matematika diterapkan sejak dini yang memiliki peranan penting dalam kehidupan manusia dan perkembangan ilmu pengetahuan dan teknologi. Kemampuan matematika dapat membantu anak mengetahui dan mengaplikasikan permainan matematika dalam kehidupan sehari-hari. Belajar matematika awal dapat melalui permainan seperti permainan sorting color yang diciptakan oleh peneliti, yang dimana disini bertujuan untuk anak dapat mengelompokkan benda sesuai dengan warnanya, bentuknya, ukurannya, dan juga beratnya. Anak belajar dimulai dari barang yang nyata hingga sampai dengan pemikiran abstark, sehingga membuat anak menjadi tidak bosan dalam mengerjakan sesuatu hal.

\section{DAFTAR PUSTAKA}

Anshori, M. \& Iswati, S. 2019. Metodologi penelitian kuantitatif: edisi 1. Surabaya: UNAIR

Aprilianti, R. (2017). Meningkatkan Kemampuan Membilang Angka 1 Sampai 20 Melalui Permainan Bendera Pintar Pada Anak Usia 5-6 Tahun. Jurnal Golden Age, 1(02), 90-102.

Arikunto, S. 2010. Prosedur Penelitian Suatu Pendekatan Praktik. Jakarta: Rineka Cipta

Brewer, Jo Ann.2007.Early Childhood Education, Preschool Trough Primary Grades. Boston: Pearson Education,Inc

Hapsari, M. N., Ilhami, B. S., \& Agustina, Y. (2019). Dekak-Dekak Geometri, Media Pembelajaran Untuk Mengenalkan Bentuk Geometri Pada Anak Kelompok A. Jurnal Golden Age, 3(01), 30-36.

Kennedy, Tipps Johnson. 2008. Guiding Childrens Learning of Mathmatict. Wadsworth: Cengage Learninng. Boston:Cengange Learning

Lasuka, Maya. 2018. Meningkatkan Kemampuan Pra Matematika Dengan Menggunakan Media Balok Cuisenaire Pada Anak Kelompok A2 PAUD Haqiqi Kota Bengkulu. Jurnal Ilmiah Potensia (Vol. 3 No. 1), 18-23

Lestari,Evi Dwi.2016. Peningkatan Kemampuan Mengenal Warna Melalui Kegiatan Klasifikasi Kancing Warna Pada Anak Usia 4-5 Tahun. Jurnal PAUD Teratai (Volume 05 Nomor 01 Tahun 2016), 220-224

Lwin, May. Dkk. (2005). Cara Mengembangkan Berbagai Komponen Kecerdasan. Jakarta: Indeks

Nisa,Titin Faridatun, dkk.2016. Membangun Karakter Anak Usia Dini Melalui Pembelajaran Math Character. Jurnal Pedagogia (Vol.5 No.2),113-124 http://ojs.umsida.ac.id/index.php/pedagogia/article/view/241

Nurhazizah.2014.Peningkatan Kemampuan Matematika Awal Melalui Strategi Pembelajaran Kinestetik. Jurnal Pendidikan Usia Dini (Vol.8(2)), 337-346 
Jurnal Golden Age, Universitas Hamzanwadi

Vol. 04 No. 1, Juni 2020, Hal. 143-151

E-ISSN : 2549-7367

Sugiyono.2013. Metode Penelitian: Kuantitatif, Kualitatif, Dan $R \& D$. Bandung: Alfabeta.

Utoyo, Setiyo.2017. Metode Pengembangan Matematika Anak Usia Dini. Gorontalo :Ideas Publishing.

Wati, Nanik indah. 2019. Pengaruh Kegiatan Finger Painting Terhadap Perkembangan Motorik Halus Anak Kelompok A Di Ra Miftahul Ulum 1 Karang Poh Kluwu Wonorejo Pasuruan. ISBN :978-602-71750-7, 5 